\title{
PENGARUH AKUPRESUR DALAM MENGURANGI NYERI PERSALINAN KALA 1 FASE AKTIF PADA PRIMIGRAVIDA Di BPMNgadilah Kecamatan Pakis - Malang
}

\author{
Yuniar Angelia P, DesyLokawati. \\ Program Studi D3 KebidananSTIKESWidyagamaHusada \\ yuniar80@yahoo.co.id \\ Program Studi D3 Kebidanan STIKES WidyagamaHusada \\ desylokaw@yahoo.com
}

\begin{abstract}
Labor pain is physiological process that occurs during the childbirth. The labor pain can be overcome through the non-pharmacological methods, one of those is acupressure in order to stimulate endorphin hormone in the blood. Endorphins are chemicals produced by our body to release pain. Based on the preliminary study conducted on20 March 2014, there were 5 childbirths that were given the relaxation technique. This research was conducted to find out the effect of acupressure to overcome the labor pain that that occurs to primigravida.

The design of the research was experimental using one group pretest-posttest. Purposive sampling was applied to 15 respondents. The data analysis was conducted using Wilcoxon Sign Rank Test. The findings showed that the value of Asymp. Sig. 0,03. It means, when the Asymp. Sig < 0,05, H0 was rejected and Hi was accepted. Thus, it can be concluded that acupressure can decrease the labor pain in the first stage of active phase.
\end{abstract}

Keyword: 


\begin{abstract}
ABSTRAK
Nyeri persalinan merupakan proses fisiologis yang dialami selama proses persalinan. Nyeri tersebut dapat diatasi dengan metode non farmakologi, salah satunya adalah akupresure. Dimana akupresure dapat merangsang pengeluaran hormon endorphin dalam darah. Endorphin adalah zat penghilang rasa sakit yang secara alami diproduksi oleh tubuh. Berdasarkan studi pendahuluan pada tgl 20 Maret 2014 diantara 5 persalinan, semuanya hanya diberikan teknik relaksasi dan belum menggunakan metode akupresure. Penelitian ini bertujuan untuk mengetahui pengaruh akupresur terhadap nyeri persalinan ibu primigravida. Desain penelitian yang digunakan adalah one group pretest-postest. Teknik sampling menggunakan purposive sampling dengan jumlah responden 15 orang. Analisa data menggunakan Wilcoxon Sign Rank Test, dimana untuk mengetahui pengaruh akupresure untuk mengurangi nyeri persalinan.Berdasarkan hasil analisa menggunakan Wilcoxon didapat nilai Asymp. Sig. 0,03. Dimana apabila nilai Asymp. Sig < 0,05 maka Ho ditolak dan $\mathrm{H}_{1}$ diterima. Sehingga dapat disimpulkan bahwa ada pengaruh akupresure dalam mengurangi nyeri persalinan kala 1 fase aktif. Diharapkan dapat menjadi alternatif pengobatan non-farmakologi dalam mengurangi nyeri persalinan yang bisa dilakukan oleh bidan maupun ibu bersalin
\end{abstract}




\section{PENDAHULUAN}

Semua wanita mengalami nyeri selama persalinan, hal ini merupakan proses fisiologis. Secara objektif sebagaimana telah dilakukan penelitian oleh Niven dan Gijsbern tahun 2004, didapatkan bahwa nyeri persalinan melebihi keadaan penyakit. Nyeri harus diatasi, Browridge 2005 menyatakan nyeri yang menyertai kontraksi uterus mempengaruhi mekanisme fungsional yang menyebabkan respon stress fisiologis, nyeri persalinan lama menyebabkan hiperventilasi dengan frekuensi pernafasan 60-70 kali per menit sehingga menurunkan kadar $\mathrm{PaCO} 2 \mathrm{ibu}$ dan peningkatan $\mathrm{pH}$. Apabila kadar $\mathrm{PaCO} 2$ ibu rendah, maka kadar $\mathrm{PaCO} 2$ janin rendah sehingga menyebabkan deselerasi lambat denyut jantung janin, nyeri meyebabkan aktivitas uterus yang tidak terkoordinasi yang akan mengakibatkan persalinan lama, akhirnya dapat mengancam kehidupan janin dan ibu, selain itu nyeri yang lama dan tidak tertahankan akan menyebabkan meningkatnya tekanan sistol sehingga berpotensi terhadap adanya syok kardiogenik (Mander, 2003). Nyeri persalinan yang tidak tertahankan mendorong ibu bersalin menggunakan obat penawar nyeri seperti analgetik dan sedativa (Basuki, 2008), sedangkan obatobat tersebut memberikan efek samping merugikan meliputi fetal hipoksia, resiko depresi pernapasan neonatus, penurunan Heart Rate / Central nervus system (CNS) dan peningkatan suhu tubuh ibu dapat menyebabkan perubahan pada janin (Mander, 2003).

Metode yang dilakukan untuk menurunkan nyeri persalinan, baik secara farmakologi maupun non farmakologi. Penggunaan metode farmakologi mempunyai efektifitas lebih baik dibanding dengan metode nonfarmakologi, namun penggunaan metode farmakologi sering menyebabkan efek samping dan kadang tidak memiliki efek yang diharapkan. Sedangkan metode nonfarmakologi selain menurunkan nyeri pada persalinan juga mempunyai efek noninvasif, sederhana, efektif, dan tanpa efek membahayakan (Basuki, 2008)

Akupresur adalah tindakan sangat sederhana, mudah dilakukan, memiliki efek samping minimal, dan aplikasi prinsip healing touch pada akupresur menunjukkan perilaku caring dapat mendekatkan hubungan terapeutik perawat dan pasien. Tehnik akupresur sebagai salah satu metode non farmakologi diharapkan dapat membantu perawat dalam persiapan ibu dan keluarga menghadapi persalinan sehingga kebutuhan ibu selama persalinan untuk mendapatkan pengalaman menyenangkan dengan rasa nyeri minimal dapat terpenuhi (Sukanta, 2001).

Berdasarkan studi pendahuluan yang dilakukan pada tanggal 20 Maret 2014, ibu bersalin di BPM Ngadilah dari 5 persalinan yang hanya dilakukan teknik relaksasi, 3 diantaranya tidak merespon dengan positif, cenderung berteriak dan menangis. Sedangkan 2 diantaranya dapat merespon dengan positif dengan beristigfar. Di BPM Ngadilah metode akupresur belum pernah digunakan untuk mengatasi nyeri persalinan ibu hanya disarankan nafas panjang dan menggunakan massase punggung.

\section{METODE PENELITIAN}

Desain yang digunakan dalam penelitian ini adalah pra-eksperimen, dengan jenis desain berbentuk desain one group pretestpostest. Dalam desain ini subyek dilakukan pengukuran awal (prettest) setelah itu dikenai perlakuan kemudian dilakukan pengukuran akhir (posttest). Hasilnya dilakukan analisis, apakah ada perbedaan atau perubahan-perubahan.

Teknik sampling menggunakan purposive sampling dengan jumlah 
responden 15 orang. Data yang terkumpul dilakukan: editing, coding, scoring, transfering, tabulating, selanjutnya dianalisis menggunakan Wilcoxon Sign Rank Test, dimana untuk mengetahui pengaruh akupresure untuk mengurangi nyeri persalinan.

\section{HASIL DAN PEMBAHASAN}

Hasil pengukuran skala nyeri yang dilakukan 10mnt sebelum pemberian akupresure pada inpartu kala 1 fase aktif menunjukkan bahwa sebanyak $80 \%$ responden mengalami nyeri berat dan $13,3 \%$ mengalami nyeri sangat berat. Hal tersebut selaras dengan pernyataan Steer dalam Baker (2001) yang menjelaskan hasil studinya di Ingris terhadap wanita yang melahirkan didapatkan 89,5\% merasakan nyeri berat atau nyeri yang tidak tertahankan.

Berdasarkan data distribusi frekuensi, responden yang mengalami nyeri sangat berat sejumlah $13,3 \%$, hal tersebut dikarenakan bertambahnya pembukaan serviks dan kontraksi yang semakin adekuat, hal ini menyebabkan nyeri semakin berat dan ibu tidak dapat mengontrol.

Setelah di berikan akupresure pada 15 responden dapat diambil kesimpulan bahwa 4 responden $(26,6 \%)$ mengalami nyeri sedang, 12 responden (73,3\%) mengalami nyeri berat, dan tidak ada responden yang mengalami nyeri sangat berat.

Hal tersebut sesuai dengan pernyatan Lee, Chang \& Kang,( 2001) yang menyatakan bahwa akupresur pada titik LI4 secara umum dapat merangsang pengeluaran endorphin dalam darah sehingga nyeri selama persalinan dapat terkontrol. Akupresur juga dapat merangsang pelepasan oksitosin dari kelenjar hipofisis, yang secara langsung merangsang kontraksi rahim. Selain itu rangsangan akupresur menurut teori gate controle mengakibatkan pesan yang berlawanan yang lebih kuat, cepat dan berjalan sepanjang serat saraf kecil gelatinosa lalu memblokir pesan nyeri sehingga otak tidak mencatat pesan nyeri tersebut.

Penurunan skala nyeri dari 15 responden yang telah diberikan akupresure sejumlah 10 responden $(66,6 \%)$ mengalami penurunan skala nyeri, 4 responden $(26,6 \%)$ skala nyeri tetap, dan 1 responden $(6,6 \%)$ mengalami peningkatan pada skala nyeri.

Pada uji statistik tabel 5.12 menggunakan Wilcoxon Sign Rank Test, syarat $\mathrm{H}_{0}$ diterima atau tidak bergantung pada nilai probabilitasnya. Dimana apabila nilai Asymp. Sig. (2-tailed)> 0,050 maka $\mathrm{H}_{0}$ diterima, apabila nilai probabilitasnya < 0,050 maka $\mathrm{H}_{0}$ ditolak.

Hasil uji statistik menggunakan Wilcoxon Sign Rank Test didapat nilai Asymp. Sig 0,033 sehingga $\mathrm{H}_{0}$ ditolak dan $\mathrm{H}_{1}$ diterima. Dengan demikian dapat disimpulkan bahwa akupresure dapat mengurangi nyeri persalinan kala 1 fase aktif pada primigravida.

Hasil penelitian ini selaras dengan hipotesis Tournaire and Theau-Yonneau, (2007) yang menyatakan bahwa akupunktur poin memiliki sifat listrik yang jika dirangsang, dapat mengubah tingkat neurotransmitter di tubuh selain itu endorfin dilepaskan karena aktivasi dari rangsangan akupunktur. Hipotesis ini telah dibuktikan oleh Ternov dkk. (2003) yang melaporkan bahwa $58 \%$ perempuan dalam kelompok akupunktur tidak memerlukan anestesi selama persalinan, dibandingkan dengan $14 \%$ perempuan dalam kelompok kontrol. 


\section{KESIMPULAN}

a. Sebelum diberikan akupresure sebanyak $6,6 \%$ responden mengalami nyeri sedang, $80 \%$ responden mengalami nyeri berat, dan 13,8\% responden mengalami nyeri sangat berat.

b. Setelah di berikan akupresure, sebanyak $26,6 \%$ responden mengalami nyeri sedang, 73,3\% mengalami nyeri berat, dan tidak ada responden yang mengalami nyeri sangat berat.

c. Pengaruh akupresure dalam mengurangi nyeri persalinan juga dapat dilihat dari 15 responden 10 diantaranya mengalami penurunan intensitas nyeri. Selain itu juga dapat dihitung menggunakan wilcoxon sign rank test, dimana nilai Asymp. Sig<0,050.

\section{SARAN}

a. Hasil penelitian ini diharapkan dapat meningkatkan kualitas pelayanan bidan pada ibu bersalin dalam memberikan kenyamanan selama proses persalinan yaitu dengan memberikan akupresure sebagai alternative dalam mengurangi nyeri persalinan pada inpartu dalam rangka mewujudkan Gerakan Sayang Ibu.

b. Hasilpenelitianinidiharapkandapatmem berikaninformasi kepadaibu bersalinterutamapadaibu bersalin yangfisiologisbahwa akupresure sangat efektif dalam mengurangi nyeri persalinan.

\section{DAFTAR PUSTAKA}

Ali, I. (2005). Taklukkan Penyakit dengan Akupresur Perut dan Ramuan Tradisional. Tangerang: Agromedia Pustaka.

Andarmoyo, S. (2013). Konsep dan Proses Keperawatan Nyeri. Yogyakarta: ArRuz Media.

Andarmoyo, S. (2013). Persalinan Tanpa Nyeri Berlebihan. Yogyakarta: ArRuz Media.
Aziz, d. (2007). Metode Penelitian Kebidanan dan Teknik Analisi Data. Jakarta: Salemba Medika.

Basuki, I. (2008). Penanganan Nyeri Persalinan dengan Metode Non Farmakologi . Bandung: Bayu Media Publishing.

Brown, Douglas \& Flood (2001). Women's Evaluation of IntrapartumNonpharmakological Pain Relief Method Used during Labor. The Journal of Perinatal Education.Vol 10. No 3

Budi, N. S. (2005). Terapi Akupresur Untuk Penyembuhan Segala Penyakit. Jakarta: Diglosia.

Chung, L.,Hung, L., Kuo, S., Huang, C. (2003). Effects of LI4 and BL 67 Acupressure on Labor Pain and Uterine Contractions in the First Stage of Labor Journal of Nursing Research Vol. 11, No. 4, 2003.

Fengge, A. (2012). Terapi Akupresur. Yogyakarta: Corp Circle Corp.

Hidayat, A. A. (2012). Metode Penelitian Kebidanan dan Teknik Analisis Data. Jakarta: Salemba Medika.

Imron, M. (2010). Metode Penelitian Bidang Kesehatan Bahan Ajar Untuk Mahasiswa. Jakarta: CV Saging.

Lee, M., Chang, S. \& Kang, D. (2004). Effect of SP6 Acupressure on labor Pain and Lengt of Delivery Time in Women During Labor. The Journal of Alternative and Complementary Medicine, Vol 10.

Mander, R. (2003). Pain in Childbearing and its control. Jakarta: EGC.

Nursalam, d. (2006). Metode Penelitian Kesehatan . Jakarta: Salemba.

Ratri, R. K. (2013). Persalinan Tanpa Nyeri Berlebihan: Konsep dan Aplikasi Manajemen Nyeri Persalinan. Yogyakarta: Ar-Ruz Media.

Potter \& Perry. (2007). Buku Ajar Fundamental Keperawatan: Konsep, 
Proses, dan Praktik. Volume 2.

Edisi 4. Jakarta: Salemba Medika.

Sujiyatini, D. (2011). Asuhan Kebidanan

(Persalinan).Yogyakarta: Rohima Press.

Sukanta, P. O. (2001). Akupresur dan Minuman Untuk Mengatasi Gangguan Pencernaan. Jakarta: Elex Media Komputindo.

Sukanta, P. O. (2003). Akupresur dan Minuman Untuk Mengatasi Gangguan Kesehatan Reproduksi. Jakarta: Elex Media Komputindo.

Tamsuri, A. (2007). Konsep dan Penatalaksanaan Nyeri . Jakata: EGC.

Winkjosastro., Hanifa et.al.(2005). Ilmu

Kebidanan.Jakarta:Yayasan Bina

Pustaka Sarwono Prawirohardjo. 